\title{
Macroeconomic Impacts of Monetary Variables on Pakistan's Foreign Sector
}

\section{Aslam Chaudhary and Ghulam Shabbir"}

\begin{abstract}
This study examines the impact of monetary variables on the balance of payments of Pakistan. Besides, exogoneity of monetary variables is also tested. The empirical findings of the study show that balance of payments is a monetary phenomenon and monetary policy could be useful in improving the foreign sector. The studies so far have not confirmed this effect. The study also shows that an increase in price level and real income lead foreign reserves to inflow. However, an increase in the interest rate, money multiplier and domestic credit lead international reserves to outflow. Partial sterilisation was evident in the short run. But in the long run, it tends to be equal to minus one, indicating no sterilisation effect on the foreign reserve movements. The central implication derived from the study is that an increasing government budget deficit leads to excessive expansion in domestic credit creation and as a result a loss of foreign reserves. The null hypothesis for exogoneity of price level, real income, interest rate and inflation rate to foreign reserves is accepted. However, the null hypothesis for the exogoneity of domestic credit is rejected for the general model but accepted for the linear model. It appears that monetary policy is effective in Pakistan
\end{abstract}

\section{Introduction}

Most underdeveloped economies face several economic problems such as budget deficit, chronic balance of payments deficit, debt servicing, low productivity and domestic resource mobilisation (Chaudhary and Abe, 1999, Naqvi, 1973 and Khan, Bilquees and Kemal 1980, Khan 1996 and Khan 1974). Moreover, they also face the problem of slow growth of exports and increasing demand for imports to accelerate their economic growth which creates a balance of payments problem, that has several impacts. Thus,

\footnotetext{
* The authors are Professor at the University of the Punjab, Lahore and Lecturer at Government College, Bhera, respectively. The authors are thankful to Dr. G. M. Arif for valuable comments which helped to improve the study. The views expressed are entirely those of the authors.
} 
balances of payments deficit deserves special attention (Mundell, 1973). There is hardly any country in the world that does not rely to some degree for its national well being on international trade and payments. This veracity is mostly seen in the case of developing countries, whose trade and payments magnitudes are particularly large in relation to domestic economic activity (Killick, 1981). The management of balance of payments is, thus, of great importance to the economic growth of such countries and Pakistan in particular. Pakistan's balance of trade remains in deficit since its birth ${ }^{1}$.

Conventionally, the theory of balance of payments adjustment mechanism is viewed as a succession of approaches: the Hume's price specie flow mechanism, the elasticity approach, the Keynesian Multiplier or income approach, the absorption approach and the policy approach that stresses internal and external balance. However a new approach is developed, which centers on the idea that the balance of payments is essentially a monetary phenomenon. It is known as the monetary approach to the balance of payments adjustment mechanism. The essence of the approach is its consistent insistence that the balance of payments is a monetary and not a real phenomenon as postulated by the conventional theories. The major point of departure of this theory from other theories is the recognition of the fact that disequilibria in the balance of payments of a country involve the inflow and outflow of foreign exchange, caused by money market disequilibrium.

The balance of payments is closely related with different aspects of the economic system because it describes the transaction of all the residents of the country with the rest of the world. These connections are the basic grounds for the emergence of various approaches to the balance of payments analysis. The classical theory began with David Hume's price-specie-flow mechanism, of the mercantilist belief that a country could achieve a persistent balance of trade surplus by import-substituting and exportpromoting policies. According to price-specie-flow mechanism, a temporary rise or fall of the general price level in the country is due to excessive or deficient supply of money relative to demand. This relative price level movement leading to a balance of trade deficit or surplus alters the stock of money in the direction of equilibrium.

The Elasticity approach associated with Robinson, (1937) and chronologically the first of 'Non classical' or 'Keynesian' approaches to the balance of payments theory and analysis involves the application of Marshallian partial equilibrium analysis to the separate markets for exports

\footnotetext{
${ }^{1}$ It is true for more than fifty years, out of fifty four.
} 
and imports on the assumption that capital movements are excluded so that an excess or deficiency of the value of exports in relation to the value of imports gives rise to a balance of payments surplus or deficit as one aspect of equilibrium. In the Keynesian multiplier approach, Harberger (1950) and Laursen and Metzler (1950) simplified the approach by assuming a two-good international economy (exportable and importable goods only) and production of export goods at constant domestic money cost. According to this an extra demand for domestic output created by a successful devaluation will be satisfied by re-employing some of the unemployed and that, because part of it will be saved, the extra income generated by increased employment will not increase demand adequately to wipe out the initial improvement in the balance of payments.

In the 'Absorption Approach' Alexander (1952) argues that devaluation will produce an inflationary price rise that will cancel out the initial relative price effect, unless inflation itself deflates the aggregate demand for goods through an income redistribution effect or through a reduction in the real value of existing money balances. In the 'economic policy approach' Tinbergen (1952) and Meade (1951) analyse devaluation, not only as an arbitrary policy change but also as one of the two independent policy instruments (wage price flexibility and devaluation) required to achieve the two policy objectives of full employment (internal balance) and a balanced balance of payments (external balance). The implicit assumption underlying these approaches is that balance of payments disequilibria are permanent.

A new approach, which describes that balance of payments, is essentially a monetary phenomenon has developed. It originated in the 1950s, by Polak (1957) and his associates at the IMF, and developed in the 1960s and 1970s by Mundell (1968) and Johnson (1972). The major point of departure of the new approach is the recognition of the fact that a country's imbalance of payments deficit (surplus) would ceteris paribus, experience a change in its money stock. The main distinguishing feature of the new approach to the payments problem is its focus upon the monetary implications of balance of payments disequilibria. The balance of payments problems are monetary problems in a monetary world economy is basically the assertion of the proponents of the approach (Musa, 1976). The monetary approach assumes that the demand for real money balances is a conventional function for real income and interest rate and it is always stable. The goods and financial assets markets are perfectly mobile at the international level. The country for which the balance of payments is to be analysed is small relative to the world in the sense that it cannot affect world prices or the interest rate. Real forces, independent of the monetary factors determine 
real output. These assumptions imply that the domestic price level and interest rates are determined exogenously. The demand for real money balances is a conventional function of real income and the interest rate and it is stable. Domestic output level is assumed to be determined exogenously. Domestic component of money supply is also exogenous. The goods and financial markets are perfectly mobile. The approach is applicable to a small country. Besides, real forces determine real output. Of course, most of these assumptions may not be applicable to developing countries. But with the liberalisation programmes and introduction of WTO reforms, Pakistan's economy is liberalised and interference of the public sector has been significantly minimised (Chaudhary 2003 and Chaudhary and Ahmed 2004).

Any disequilibrium in the money market is expected to be adjusted through changes in the international reserve flows under the fixed exchange rate system and changes in exchange rate when the economy is operating under the flexible exchange rate regime. ${ }^{2}$ This proposition was tested by the 'reserve-flow equation' (Kreinin and Officer, 1976). A reserve-flow equation is an equation in which the dependent variable is either the level of the country's international reserves, the change in reserves or the rate of change in reserves (Connolly and Taylor 1976). The explanatory variables were interest rate, government expenditure, money multiplier, money stock, price index, exchange rate, and demand for nominal and real money balances and so on. Within this range, the explanatory variables may however vary from study to study. Using this equation, Courchene (1973); De Granwe (1976); Bilquees (1989) and Nwaobi (2003) got negative results, and Courchene and Singh (1976); Donna (1976); Cos and Wilford (1977); Wildford and Zecher (1979); Bhattia (1982); Odedokum (1997) and Howaed and Mamingi (2002) got positive results. Whereas Bean (1976); Connolly and Taylor (1976); Genberg (1976); Aghevli and Khan (1977); Guitan (1976); Sohrab-ud-din (1985) and Zecher (1976) got mixed results.

In the case of Pakistan, studies carried out by Sohrab-ud-Din (1985) and Bilquees (1989) showed that the monetary approach to balance of payments is not valid for Pakistan. The problem of these studies is that both studies have not tested the basic assumption of the monetary approach i.e. the exogoneity of money demand determinants and domestic credit with respect to foreign reserves. If the monetary approach to the balance of payments assumptions regarding exogoneity are not verified, then the estimation procedure would be inconsistent. ${ }^{3}$ Moreover, Bilquees's study also

\footnotetext{
${ }^{2}$ See Hossain (1988), pp. 66.

${ }^{3}$ For detail see: Jame, M. Johannes (1981).
} 
suffers from quality of data. She generated her own series of representative data for present Pakistan for some variables. Data for some variables may not exist before 1971. Thus, it was not actual data for the variable used for estimation. Besides her period of study and its results are hardly useful for the formulation of current polices. The very reason that the present economic structure is more liberal than that of the early period; when the public sector controlled over 90 percent of bank deposits and fixed exchange rate was the rule for foreign sector and trade (Chaudhary 2003). Presently Pakistan's economy is liberalised to the extent that there is no fixed exchange rate, tariff barriers have been reduced, trade is much liberalised, the financial market is moving towards the free market and the central bank has much autonomy. In the light of the above, there is a need for a fresh study, which must be up to date, and not suffering from the above cited drawbacks, so that it is useful for current policy formulation.

\section{Methodology}

The monetary approach to the balance of payments relates the balance of payments directly to the demand for and supply of money. In the closed economy analysis, the main interest is focused on the affects of variations in the nominal stock of money (monetary base), on interest rate, output and domestic price level. However, in a small open economy, the money supply can no longer be considered an exogenous instrument because it can be made to change through surpluses and deficits in the balance of payments. Therefore, it can be said that the monetary approach to the balance of payments is concerned with the relationship between the domestic component of money stock, prices, output, interest rate and the balance of payments.

In general, an excess demand for goods, services and financial assets creates disequilibrium in the balance of payments. Under the fixed exchange rate system the quantity of money is a key mechanism for attaining and maintaining monetary equilibrium. For instance, with the excess supply of money over demand, the residents must adjust their portfolios by purchasing foreign goods and assets in order to achieve monetary equilibrium. For this purpose, residents can purchase reserves from the central bank to make payments to foreigners, which decreases the domestic money supply until equilibrium is achieved. In this sense, the balance of payments is a monetary phenomenon. The formal monetary model of the balance of payments consists of the money demand function, a money supply equation and an equilibrium condition. 
There will be a change in money demand and supply due to variations in economic activities. So it is necessary to watch these changes for meaningful analysis. The money demand shows the economy's capacity to absorb the increased money supply. The intertemporal stability of the money demand function is crucial for monetary policy to have predictable effects on the economic variables. Three basic issues in specifying the money demand function are: the definition of money, the variables to be used in the money demand function, the stability of money demand function. ${ }^{4}$ The specific features of underdeveloped economies such as Pakistan may affect these variables differently from the case of developed countries. In less developed economies, the interest rate is included in the money demand function, as an opportunity cost of holding the money variable, which is one of the most controversial issues. Because in such economies market forces, due to the existence of dual money, do not determine market interest rate (organised and unorganised). In LDCs where the range of alternative assets is limited, substitution may take place between goods and money. Therefore, it is more appropriate to represent the opportunity cost by the interest rate and the implicit return on goods, the rate of inflation.' Thus, demand for real money balances can be written as:

$$
\mathbf{M}^{\mathrm{d}} / \mathbf{P}=\mathbf{a} \mathbf{y}^{\mathrm{b1}} \mathbf{i}^{\mathrm{b} 2} \pi^{\mathrm{b3}}
$$

Where $M^{d}$ is the demand for nominal money balances; $P$ is the domestic price level; $y$ is the level of domestic real income; $i$ is the domestic interest rate; and $\pi$ is the rate of inflation. The money supply is defined as equaling the product of money multiplier and high-powered money.

$$
M^{\mathrm{s}}=\mathbf{K m}
$$

Where $\mathrm{M}^{\mathrm{s}}$ is the supply of money; $\mathrm{K}$ is the money multiplier and $\mathrm{m}$ is the monetary base (volume of high-powered money). By definition the stock of high-powered money or the liabilities of the monetary authorities $(\mathrm{m})$ is equal to the stock of international reserves $(\mathrm{R})$ and domestic assets (net of liabilities) holdings of the monetary authorities (DC). Thus we may define it as:

$\mathbf{m}=\mathbf{R}+\mathbf{D C}$

Putting this in equation (2).

$$
\mathbf{M}^{\mathrm{s}}=\mathbf{K}(\mathbf{R}+\mathrm{DC})
$$

\footnotetext{
${ }^{4}$ See, Ahmed, (2000).

${ }^{5}$ For detail see, Faiz Bilquees, (1989).
} 
With the help of monetary equilibrium, we can derive the international reserves flows equation. The money market equilibrium will be:

$$
\mathbf{M}^{\mathrm{d}}=\mathbf{M}^{\mathrm{s}}
$$

By combining equation (1), (4) and (5), taking the variables in percentage changes, foreign reserves as dependent variable and adding intercept, we get the following foreign reserve flows equation ${ }^{6}$.

$$
\begin{aligned}
& (\mathrm{R} / \mathrm{m}) \mathrm{g} \mathbf{R}=\beta_{0}+\beta_{1} \mathbf{g P}+\beta_{2} \mathrm{~g} \mathbf{y}+\beta_{3} \mathrm{~g} \mathbf{i}+\beta_{4} \mathrm{~g} \pi+\beta_{5} \mathrm{~g} \mathbf{K}+\beta_{6} \\
& (\mathrm{DC} / \mathrm{m})+\mathrm{g} \mathrm{DC}+\mathrm{u}
\end{aligned}
$$

Equation (6) represents the key relationship in the monetary theory of the balance of payments. The expected signs and expected magnitudes of the parameters of equation (6) are as follows,

$$
\beta_{1}=1, \beta_{2}>0, \beta_{3}<0, \quad \beta_{4}<0, \quad \beta_{5}=\beta_{6}=-1
$$

The expected sign of $\beta_{1}$ implies that an increase in the rate of growth in price level (gp) improves the international reserve position because of devaluation. Devaluation is treated as a monetary phenomenon, since devaluation raises the domestic price level leading to reduction in domestic expenditures on goods and services via reduction in residents purchasing power. This leads to increase in the production of exportable goods. As a result, the level of income and employment improves. An increase in income and employment leads to increase in nominal money demand over money supply. If domestic credit is constant, the increased money demand generates capital and foreign exchange reserves inflows.

The coefficient $\beta_{2}$ is the income elasticity of demand for nominal money balances and, therefore is positive and in the neighborhood of unity. In particular, a one percent increase in income generates $\beta_{2}$ percent increase in the demand for money and consequently reserves inflows. ${ }^{7}$ Increase in interest is associated with reserves outflow in this hypothesis. Other things being the same, a given increase in the interest rate would depress the demand for money, creating an excess supply of money and consequently would result in reserves outflows. Hence, the interest rate and changes in this rate are

\footnotetext{
${ }^{6}$ For detail derivation of eq. 6 see Appendix.

7 This result may appear to be different with the absorption theory in which rising income increases imports and generates reserve outflows. However, the absorption theory is concerned with the balance of trade rather than balance of payments. (Zecher, 1974), pp. 290.
} 
assumed to reflect similar movements in interest rates all over the world. ${ }^{8}$ However, if changes in Pakistan's interest rate are dominated by changes relative to the rest of the world, the estimates of $\beta_{3}$ are such as to be positive. i.e. increase in Pakistan's interest rate relative to the rest of the world would attract capital and generate reserve inflows and vice-versa.

The coefficients of growth rates of money multiplier and domestic credit should be negative ones $\left(\beta_{5}=\beta_{6}=-1\right)$. The coefficient $\left(\beta_{6}\right)$ on domestic assets (net) called the offset coefficient and expected to have a value of minus unity (Sohrab-ud-Din, 1985). The offset coefficient indicates the degree to which changes in the domestic component of money supply are offset by the changes in international reserves (Bhatia, 1982).

\section{Exogoneity test for Monetary Theory}

The test used in this study is based on the work of Geweke (1978) and is summarised in Geweke (1978). Consider the "complete dynamics simultaneous equation model CDSEM".

$$
\text { B (L) } \mathbf{Y}_{t}+\Gamma(\mathbf{L}) \mathbf{X}_{t}=\xi
$$

$$
(\mathrm{g} \times \mathrm{g}) \quad(\mathrm{g} \times 1) \quad(\mathrm{g} \times \mathrm{k}) \quad(\mathrm{k} \times 1) \quad(\mathrm{g} \times 1)
$$

Where $B(\mathrm{~L})$ and $\Gamma(\mathrm{L})$ are matrices of polynomials in the lag operator which purports to be a complete description of the interaction between " $k$ " exogenous variables (i.e. $x_{t}$ represents observations at time $t$ on $\mathrm{k}$ putative exogenous variables) and endogonous variables $\mathrm{y}_{\mathrm{t}}$. Geweke argued that a testable implication of the hypothesis that $\mathbf{x}_{t}$ is exogenous. Since $\mathbf{x}_{t}$ is determined outside the CDSEM, a proper specification of the determinants of $x_{t}$ will not include any value of $y_{t}$. In other words, in the regression of $x_{t}$ on past $x_{t}$ and past $y_{t, .}$ i.e.

$$
X_{t}=\sum_{s=1}^{\infty} F_{s} X_{t-s}+\sum_{s=1}^{\infty} G_{s} Y_{t-s}+\xi t_{t}
$$

Where:

\footnotetext{
${ }^{8}$ Under the current international monetary system in which the financial markets have become more integrated, the domestic and foreign interest rates move together. Hamburger (1977) argued that the domestic and foreign interest rates generally move together and when they do, it is the domestic interest rate that determines the amount of money held by the public.
} 


$$
\begin{aligned}
& x_{t}=\text { Exogenous variables }(g \mathrm{p}, \mathrm{g} \mathrm{y}, \mathrm{g} \mathrm{i}, \mathrm{g} \pi \text { and } \mathrm{g} \mathrm{dc}) \\
& \mathrm{y}_{\mathrm{t}}=\text { Endogenous variables }(\mathrm{g} r) \\
& \mathrm{Fs}_{\mathrm{s}}=\text { Coefficients of lagged exogenous variables } \mathrm{x}_{\mathrm{t}} \\
& \mathrm{Gs}=\text { Coefficients of lagged endogenous variables } \mathrm{y}_{\mathrm{t}} \\
& \epsilon_{\mathrm{t}}=\text { error term. }
\end{aligned}
$$

There "exists a CDSEM with exogenous $x_{t}$ and endogenous $y_{t}$ and no other variables, if and only if $\mathrm{Gs}=0$ for all $\mathrm{s}>\mathrm{o}$. The main purpose of the analysis is to test the hypothesis of exogoneity of price level, real income, interest rate, rate of inflation and domestic credit with respect to reserve flows. Using the Wald statistics we test the null hypothesis that Gs = 0 for all $s>0$. Under the null hypothesis both tests are asymptotically distributed as a Chi-square with degree of freedom equal to the number of regressions.

\section{Empirical Results}

The annual data is utilised from International Financial Statistics. All the series are stationary at level. For this purpose, Augmented Dicky-Fuller $(\mathrm{ADF})$ and Phillips-Perron (PP) tests are used; results are reported in appendix Table- 1 . The foreign reserve equation (6) is estimated by Simple OLS for the period (1965-99) using the broad (M2) definition of money. The Chow Break point test is carried out to investigate the validity of the mode1 during the sample period. The data was divided into two periods (1965-81) and (1982-99) ${ }^{9}$. The results indicate that the model was stable for the whole period. This means that there is no change or any shift in the reserve flow equation between the periods of fixed exchange rate and managed floating exchange rate regimes.

The results reported in Table (1) show that the positive signs of the growth rate of prices and real income confirm the proposition of the monetary approach but do not support the assumption of linear homogeneity in prices. These results also indicate that, if all other things are equal then a rise in growth rate of the prices and real income will lead to reserve inflows. Moreover, the view that interest rate and inflation both

\footnotetext{
${ }^{9}$ The Chow test is carried out to investigate the validity of the model during the sample period. For this, the data was divided into two periods.
} 
should be used to measure the opportunity cost of holding money in less developed countries is also supported by this study's finding. The domestic credit coefficient (offset coefficient) is statistically different from -1 , the value predicted by the monetary model. This would imply that all increases in this variable would not totally leak out through reserve outflows. It means that the government sterilises the reserves through domestic credit in less developed countries such as Pakistan.

The coefficient of income shows that an increase in income at an annual rate of $10 \%$ will generate reserve inflows of $11.9 \%$, while the same increase in growth rates of interest, inflation, money multiplier and domestic credit will lead to reserve losses of $1.5 \%, 6.25 \% 2.13 \%$ and $8.22 \%$, respectively. Thus, the effect of domestic credit expansion on international reserve out flows is more than other variables in the long run. Therefore, the movements in growth rate of domestic credit reflect the behaviour of monetary policy. The results portray the true picture of Pakistan's economy; where the government often fails to collect enough revenues to meet its requirements. As such the monetary authorities are forced to expand domestic credit irrespective of its adverse effects on the economy.

The results of this study support the monetary approach to the balance of payments, as also stated by others, for example, Courchene and Singh (1976); Donna (1976); Zecher (1976); Akhter, Putnam, and Wilford, (1977); Wildford and Zecher (1979); Bhattia (1982); and Howard and Mamingi (2002) found similar results. All these studies concluded that balance of payments is a monetary phenomenon and monetary policy is useful in dealing with it. But our results for Pakistan do not support the results found by Sohrab-ud-Din (1985) and Bilquees (1989).

The reason for this deviation lies perhaps in the definition of inflation ${ }^{10}$ and use of different time period for this study. Besides, our study has a larger sample;

\footnotetext{
${ }^{10}$ Bilquees used growth rate of GNP deflator and CPI as proxy for the growth rate of inflation and growth rate in prices in the same equation. But we use the growth rate of inflation as $\mathrm{g} \pi=[\log \mathrm{CPI}(-1)-\log$ CPI (-2)] as used by Aghevli and Khan (1977), Khan (1996).
} 
Table 1: Estimates of Foreign Exchange Reserve Flows Equation for Pakistan: (1965-99)

\begin{tabular}{lccc}
\hline \multicolumn{1}{c}{ Variables } & \multicolumn{3}{c}{ Coefficients } \\
\cline { 2 - 4 } & $\mathbf{( 1 )}$ & $\mathbf{( 2 )}$ & $\mathbf{( 3 )}$ \\
\hline Constant & -1.238 & -0.321 & -2.09 \\
& $(-2.33)^{* *}$ & $(-3.36)^{*}$ & $(-4.34)^{*}$ \\
Price level & 0.001 & 0.0002 & 0.001 \\
& $(1.64)^{* * *}$ & $(0.98)$ & $(2.41)^{* *}$ \\
Real income & 1.19 & 0.835 & 1.480 \\
& $(5.99)^{*}$ & $(26.14)^{*}$ & $(8.047)^{*}$ \\
Interest rate & -0.15 & -0.236 & ---- \\
& $(-2.70)^{*}$ & $(-4.92)^{*}$ & ---- \\
Inflation rate & -0.625 & ---- & -1.166 \\
& $(-1.84)^{* * *}$ & ---- & $(-3.80)^{*}$ \\
Money Multiplier & -0.213 & -0.145 & -0.244 \\
& $(-3.26)^{*}$ & $(-1.98)^{* *}$ & $(-3.38)^{*}$ \\
Domestic credit & -0.822 & -0.811 & -0.823 \\
& $(-35.16)^{*}$ & $(-29.55)^{*}$ & $(-32.08)^{*}$ \\
MA & 0.941 & 1.39 & 0.989 \\
& $(16.28)^{*}$ & $(5.69)^{*}$ & $(1652.02)^{*}$ \\
\hline R-Squared & 0.987 & 0.991 & 0.984 \\
Adjusted R- & 0.984 & 0.989 & 0.981 \\
Squared & & & \\
S.E. of Regression & 0.017 & 0.014 & 0.019 \\
Durbin-Watson & 1.98 & 1.40 & 2.33 \\
Stat. & & & $302.87^{*}$ \\
F-statistic & $311.57^{*}$ & $530.65^{*}$ & 1.34 \\
Chow Breakpoint Test: & & & \\
F-statistic & 1.60 & 0.281 & \\
\hline
\end{tabular}

* = Significant at $1 \%$ leve1

** $=$ Significant at $5 \%$ leve1

*** $=$ Significant at $10 \%$ level

Therefore, these results are more reliable than the earlier studies, which were based on a shorter period. Our findings support the monetarist hypothesis of the balance of payments despite all restrictive assumptions behind the theory.

To test the exogoneity of the determinants of money demand (domestic price level $\mathrm{P}$, real income $\mathrm{y}$, interest rate (i) and inflation $(\pi)$ and 
domestic credit DC with respect to reserves $\mathrm{R}$, two tests are carried out. In the first test, data is constructed as they appear in equation (6). In the second test, first difference of $\mathrm{R}, \mathrm{P}, \mathrm{y}, \mathrm{i}, \pi$ and $\mathrm{DC}$ are used. The motivation underlying the second test is that if the test data are defined as in (6) then share weights for $\mathrm{R}$ and DC will appear on both sides of (8), and it is possible that a spurious simultaneity might be introduced.

The test results for both sets of data are displayed in appendix Table (2). The results of the first test are displayed under the heading "General model" and the results of the second test under the heading "Linear Model". The Wald Test (F-statistic and Chi-square) is used to test the null hypothesis of exogoneity; i.e., that six coefficients on lagged reserves in all five equations (one for each putative exogenous variable) are jointly zero which are displayed in column (3) and (4) of Table 2. The estimated value of F-statistic and Chi-square are insignificant, except for domestic credit. Domestic credit is significant in the general model hypothesis and the exogoneity of domestic credit is rejected for the general model but accepted for the linear model. The contradiction in domestic credit results may be a result of spurious simultaneity as suspected by Whitman (1975), Magee (1976), Borts and Hanson (1977).

\section{Conclusion and policy implications}

The study focused on analysing whether the balance of payments problem is a monetary phenomena. No study, so far, confirmed this notion. The empirical findings of this study show that balance of payments is a monetary phenomenon and monetary policy could be useful in improving the foreign sector. The increase in price level and real income lead to foreign reserve inflows whereas increase in interest rate, inflation, money multiplier and domestic credit lead to reserves outflows. This also shows that there is partial sterilisation in the short run but in the long run, it tends to equal -1 ; indicating no sterilisation policy adopted by the authorities to effect the foreign reserve movements through domestic credit creation. The results also indicate that excessive domestic credit expansion will lead to reserve out flows.

This increase in prices leads to an increase in the money demand. If this rise in money demand is not met by an equal increase in money supply by the monetary authorities, then it puts pressure on reserves from abroad, until the excess demand for money is entirely eliminated. Another implication of monetary policy is that if the monetary authorities do not increase the domestic component of money supply to meet the increased money demand, resulting from the growth of GNP over time, then an 
inflow of money will take place to make up the difference. The central implication derived from this study is that an increasing government budget deficit led to excessive expansion in domestic credit and as a result, a loss of foreign exchange reserves. Thus, controlling domestic credit, as well as other monetary variables can stabilise foreign reserves. 


\section{APPENDIX 1: SPECIFICATION OF THE MODEL}

The formal monetary model of the balance of payments consists on, the money demand function, a money supply equation and an equilibrium condition

\section{Money demand function}

The demand for real money balances can be written as:

$$
M^{\mathrm{d}} / \mathrm{P}=\mathrm{a} \mathrm{y}^{\mathrm{b} 1} \mathrm{i}^{\mathrm{b} 2} \pi^{\mathrm{b} 3}
$$

Where $M^{d}$ is the demand for nominal money balances; $P$ is the domestic price leve1;

$y$ is the level of domestic real income; $i$ is the domestic interest rate; and $\pi$ is the rate of inflation. Equation (1) can be written as in $\log$ form:

$$
\begin{aligned}
& m^{d}-p=a+b_{1} y+b_{2} i+b_{3} \hat{\jmath} \\
& m^{d}=a+p+b_{1} y+b_{2} i+b_{3} \hat{\jmath}
\end{aligned}
$$

Taking derivative with respect to time and denoting it by $(\mathrm{g})$, above equation becomes as:

$$
\mathrm{g} \mathrm{m}^{\mathrm{d}}=\alpha_{0}+\alpha_{1} \mathrm{~g} \mathrm{p}+\alpha_{2} \mathrm{~g} \mathrm{y}+\alpha_{3} \mathrm{~g} \mathrm{i}+\alpha_{4} \mathrm{~g} \hat{\jmath}+\mathbf{u}
$$

Where: disturbance.

$\mathrm{g} x=(1 / \mathrm{x})(\mathrm{d} \mathbf{x} / \mathrm{dt})$, and $\mathrm{x}=\mathrm{p}, \mathrm{y}, \mathrm{i}, \hat{\mathrm{j}}$ and $\mathrm{u}$ is the stochastic

The parameters $\alpha_{2}, \alpha_{3}$ and $\alpha_{4}$ are the elasticity of real income, interest rate and rate of inflation with respect to nominal money balances respectively, which are expected to have the following signs:

$$
\alpha_{2}>0, \quad \alpha_{3}<0, \quad \alpha_{4}<0
$$

Since the demand for money is assumed to be homogeneous of degree one in price leve1, so the expected sign of $\alpha_{1}=1$. 


\section{Money supply equation}

The money supply is defined as equaling the product of money multiplier and the high-powered money.

$$
\mathrm{M}^{\mathrm{s}}=\mathrm{Km}
$$

Where $\mathrm{M}^{\mathrm{s}}$ is the supply of money; $\mathrm{K}$ is the money multiplier and $\mathrm{m}$ is the monetary base (volume of high-powered money)

By definition the stock of high-powered money or the liabilities of the monetary authorities $(\mathrm{m})$ is equal to the stock of international reserves $(\mathrm{R})$ and domestic assets (net of liabilities) holdings of the monetary authorities (DC).

$$
\mathrm{m}=\mathrm{R}+\mathrm{DC}
$$

Putting it in equation (2):

$\mathrm{M}^{\mathrm{s}}=\mathrm{K}(\mathrm{R}+\mathrm{DC})$

Writing equation in logarithmic form we get:

$\mathrm{m}^{\mathrm{s}}=\mathrm{k}+\log (\mathrm{R}+\mathrm{DC})$

Where, $\mathrm{m}^{\mathrm{s}}$ is the $\log$ of money supply $\left(\mathrm{M}^{\mathrm{s}}\right)$ and $\mathrm{k}$ is the $\log$ of money multiplier (K).

Taking derivative with respect to time and denoting it by $(\mathrm{g})$ and after some manipulation we get:

$$
\mathrm{g} \mathrm{m}^{\mathrm{s}}=\mathrm{gk}+(\mathrm{R} / \mathrm{m}) \mathrm{gR}+(\mathrm{DC} / \mathrm{m}) \mathrm{g} \mathrm{DC}
$$

Where:

$\mathrm{g} x=(1 / \mathrm{x})(\mathrm{dx} / \mathrm{dt})$, and $\mathrm{x}=\mathrm{k}, \mathrm{R}$, and DC

Equation (3a) can be written as:

$$
\mathrm{g} \mathrm{m}^{\mathrm{s}}=\mathrm{gk}+\mathrm{gr}+\mathrm{gdc}
$$

Where:

$\mathrm{g} \mathrm{m}^{\mathrm{s}}=$ Growth rate of money supply. $\mathrm{g} \mathrm{k}=$ Growth rate of money multiplier 
$\mathrm{g} \mathrm{r}=$ Growth rate of international reserves weighted by its share in monetary base .

$\mathrm{g} \mathrm{dc}=\quad$ Growth rate of domestic credit weighted by its share in monetary base.

\section{Money market equilibrium}

With the help of monetary equilibrium, we can derive the international reserves flows equation.

$$
\begin{aligned}
& g \mathrm{~m}^{\mathrm{s}}=\mathrm{g} \mathrm{m}^{\mathrm{d}} \\
& \mathrm{gk}+\mathrm{gr}+\mathrm{gdc}=\mathrm{a}+\mathrm{b}_{0} g \mathrm{p}+\mathrm{b}_{1} g \mathrm{~g}+\mathrm{b}_{2} g \mathrm{i}+\mathrm{b}_{3} g \hat{\jmath}+\mathrm{u} \\
& \mathrm{gr}=\beta_{0}+\beta_{1} g \mathrm{p}+\beta_{2} g \mathrm{~g}+\beta_{3} g \mathrm{i}+\beta_{4} g \hat{\jmath}-\beta_{5} g \mathrm{~g}-\beta_{6} g \mathrm{dc}+\mathrm{u}
\end{aligned}
$$

Equation (5) represents the key relationship in the monetary theory of the balance of payments. The expected signs and expected magnitudes of the parameters of equation (5) are as follows.

$$
\beta_{1}=1, \beta_{2}>0, \beta_{3}<0, \beta_{4}<0, \beta_{5}=\beta_{6}=-1
$$


Appendix: Table-1: The Unit Root Test of Stationarity

\begin{tabular}{|c|c|c|c|c|}
\hline \multirow[t]{2}{*}{ Variables } & \multirow{2}{*}{$\begin{array}{l}\text { Test } \\
\text { Type }\end{array}$} & \multicolumn{3}{|c|}{ Test for Unit Root in Level } \\
\hline & & Intercept & $\begin{array}{c}\text { Test Equation } \\
\text { include in Trend }\end{array}$ & None \\
\hline \multirow[t]{2}{*}{ Reserves } & $\mathrm{ADF}$ & $\begin{array}{l}-5.613280 \\
(-3.6496)^{*}\end{array}$ & $\begin{array}{l}-5.591444 \\
(-4.2712)^{*}\end{array}$ & $\begin{array}{l}-5.689652 \\
(-2.6369)^{*}\end{array}$ \\
\hline & $\mathrm{PP}$ & $\begin{array}{l}-6.361415 \\
(-3.6422)^{*}\end{array}$ & $\begin{array}{l}-6.290903 \\
(-4.2605)^{*}\end{array}$ & $\begin{array}{l}-6.468714 \\
(-2.6344)^{*}\end{array}$ \\
\hline \multirow[t]{2}{*}{ Leve1 } & $\mathrm{ADF}$ & $\begin{array}{l}-3.820057 \\
(-3.6496)^{*}\end{array}$ & $\begin{array}{l}-3.797062 \\
(-3.5562)^{* *}\end{array}$ & $\begin{array}{l}-3.869686 \\
(-2.6369)^{*}\end{array}$ \\
\hline & $\mathrm{PP}$ & $\begin{array}{l}-6.107482 \\
(-3.6422)^{*}\end{array}$ & $\begin{array}{l}-6.170552 \\
(-4.2605)^{*}\end{array}$ & $\begin{array}{l}-6.125617 \\
(-2.6344)^{*}\end{array}$ \\
\hline \multirow[t]{2}{*}{ Income } & $\mathrm{ADF}$ & $\begin{array}{l}-3.315301 \\
(-2.9558)^{* *}\end{array}$ & $\begin{array}{c}-3.235786 \\
(-3.2109)^{* * *}\end{array}$ & $\begin{array}{c}-0.828611 \\
(-1.9517)\end{array}$ \\
\hline & $\mathrm{PP}$ & $\begin{array}{c}-2.163431 \\
(-2.6148)\end{array}$ & $\begin{array}{c}-2.051565 \\
(-3.2081)\end{array}$ & $\begin{array}{r}-0.541005 \\
(-1.6211)\end{array}$ \\
\hline \multirow[t]{2}{*}{ Rate } & $\mathrm{ADF}$ & $\begin{array}{l}-4.656246 \\
(-3.6496)^{*}\end{array}$ & $\begin{array}{l}-4.574843 \\
(-3.5562)^{* *}\end{array}$ & $\begin{array}{l}-4.757654 \\
(-2.6369)^{*}\end{array}$ \\
\hline & PP & $\begin{array}{l}-5.614617 \\
(-3.6422)^{*}\end{array}$ & $\begin{array}{l}-5.563833 \\
(-4.2605)^{*}\end{array}$ & $\begin{array}{l}-5.656899 \\
(-2.6344)^{*}\end{array}$ \\
\hline $\begin{array}{l}\text { Inflation } \\
\text { Rate }\end{array}$ & $\mathrm{ADF}$ & $\begin{array}{l}-4.645548 \\
(-3.6576)^{*}\end{array}$ & $\begin{array}{l}-4.551090 \\
(-4.2826)^{*}\end{array}$ & $\begin{array}{l}-4.712595 \\
(-2.6395)^{*}\end{array}$ \\
\hline Rate & $\mathrm{PP}$ & $\begin{array}{l}-5.882468 \\
(-3.6496)^{*}\end{array}$ & $\begin{array}{l}-5.781154 \\
(-4.2712)^{*}\end{array}$ & $\begin{array}{l}-5.991086 \\
(-2.6369)^{*}\end{array}$ \\
\hline \multirow[t]{2}{*}{ Multiplier } & $\mathrm{ADF}$ & $\begin{array}{l}-3.242476 \\
(-2.9558)^{* *}\end{array}$ & $\begin{array}{l}-3.633055 \\
(-3.5562)^{* *}\end{array}$ & $\begin{array}{l}-3.298826 \\
(-2.6369)^{*}\end{array}$ \\
\hline & $\mathrm{PP}$ & $\begin{array}{l}-5.225522 \\
(-3.6422)^{*}\end{array}$ & $\begin{array}{l}-5.673861 \\
(-4.2605)^{*}\end{array}$ & $\begin{array}{l}-5.313670 \\
(-2.6344)^{*}\end{array}$ \\
\hline \multirow[t]{2}{*}{$\begin{array}{l}\text { Domestic } \\
\text { Credit }\end{array}$} & $\mathrm{ADF}$ & $\begin{array}{l}-5.524144 \\
(-3.6496)^{*}\end{array}$ & $\begin{array}{l}-5.483126 \\
(-4.2712)^{*}\end{array}$ & $\begin{array}{l}-4.568966 \\
(-2.6369)^{*}\end{array}$ \\
\hline & PP & $\begin{array}{l}-6.056990 \\
(-3.6422)^{*}\end{array}$ & $\begin{array}{l}-5.972944 \\
(-4.2605)^{*}\end{array}$ & $\begin{array}{l}-5.315551 \\
(-2.6344)^{*}\end{array}$ \\
\hline
\end{tabular}

ADF: Augmented Dickey Fuller Test, PP: Phillips-Perron Test.

( ) values show the critical $\tau$ (tau) statistics computed by MacKinnon.

* Stationary at $1 \%$ level

** Stationary at $5 \%$ level

*** Stationary at $10 \%$ leve1 
Appendix: Table 2: Regression Results for Testing Exogeneity of the Monetary Model

Test Statistic for Null Hypothesis

Gs $=0$, for all $s>0$

Wald Statistic

\begin{tabular}{|c|c|c|c|c|c|}
\hline Regression & Model & F-statistic & $\begin{array}{c}\text { Chi- } \\
\text { square }\end{array}$ & $\mathbf{R}^{2}$ & D.W.stat \\
\hline \multirow{4}{*}{ g p } & General Model & 0.459 & 0.459 & 0.99 & 2.06 \\
\hline & Linear Mode1 & $(0.511)$ & $(0.497)$ & 0.85 & 1.67 \\
\hline & & 0.244 & 0.244 & & \\
\hline & & $(0.631)$ & $(0.620)$ & & \\
\hline \multirow[t]{5}{*}{ g y } & Gen & 0 0 & סרכ 0 & 000 & 182 \\
\hline & Linear Mode1 & $(0.355)$ & $(0.335)$ & 0.77 & 2.15 \\
\hline & & 0.078 & 0.078 & & \\
\hline & & $(0.785)$ & $(0.779)$ & & \\
\hline & & & 1.634 & 0.76 & 2.05 \\
\hline \multirow[t]{4}{*}{ g i } & General Model & .634 & $(0.201)$ & 0.61 & 2.14 \\
\hline & Linear Model & $(0.227)$ & 0.500 & & \\
\hline & & 0.500 & $(0.479)$ & & \\
\hline & & $(0.495)$ & & & \\
\hline \multirow[t]{4}{*}{ g $\pi$} & General Mode1 & 0.391 & 0.391 & 0.99 & 2.42 \\
\hline & Linear Mode1 & $(0.544)$ & $(0.531)$ & 0.73 & 1.69 \\
\hline & & 0.154 & 0.154 & & \\
\hline & & $(0.702)$ & $(0.694)$ & & \\
\hline \multirow[t]{4}{*}{ gdc } & General Mode1 & $8.558^{* *}$ & $8.558 * * 10$ & 0.98 & 2.05 \\
\hline & Linear Mode1 & $(0.03)$ & 03) & 0.76 & 1.61 \\
\hline & & 1.037 & 1.037 & & \\
\hline & & $(0.365)$ & $(0.308)$ & & \\
\hline
\end{tabular}

$\mathrm{g} \mathrm{p}=$ Growth rate of domestic price level

g $\mathrm{y}=$ Growth rate of real income

$\mathrm{g} i=$ Growth rate of domestic interest rate

$\mathrm{g} \pi=$ Growth rate of inflation

$\mathrm{g} \mathrm{dc}=$ Growth rate of domestic credit

$* *$ = Significant at $5 \%$ level.

( ) value shows the probability. 


\section{References}

Aghevli, B. Bijan, 1977, "Money Prices and Balance of Payments: Indonesia 1968-73". The Journal of Development Studies, Vol. 13, No. 2, pp. $37-57$.

Aghevli, B. Bijan and Mohsin S. Khan, 1976, "The Monetary Approach to the Balance of Payments Determination: An Empirical Test." In IMF (ed.), The Monetary Approach to the Balance of Payments, Washington, D.C: International Monetary Fund, pp. 275-90

Ahmad, M., 2000, "Demand for Money in Bangladesh: An Econometric Investigation in the Basic Issues." The Indian Economic Journal, Vol. 84, No.1, pp. 84-89.

Alexander, S. S., 1952, "The Effects of a Devaluation on a Trade Balance" International Monetary Fund, Staff Paper No.2.

Bhatia, S. L., 1982, "The Monetary Theory of the Balance of Payments Under Fixed Exchange Rate: An Example of India 1951-73." The Indian Economic Journal, Vol. 29, No. 3, pp. 30-34.

Bilquees, F., 1989, "The Monetary Approach to the Balance of Payments: The Evidence on Reserves Flow from Pakistan." Pakistan Development Review, Vol. 38. No. 3, pp. 195-206.

Borts, G. H. and J. A., Hanson, 1977, "Monetary Approach to Balance of Payments” Providence, R. I., Brown University (Mimeographed).

Chaudhary M. Aslam 2003 Trade Cooperation and Economic Policy Reforms in South Asia, A Case Study of Pakistan, Research Report, TRACE Project, EU, Institute of Development Studies, Dacca, Bangladesh.

and Abe, K., 1999, Pakistan Economy: Past Trend, Current Situation and Future Prospects, Economic Journal of the Chiba University, Chiba, Japan.

Chaudhary M. Aslam and Qaisrani, A. Ashfaq, 2002, Trade Instability and Economic Growth in Pakistan, Pakistan Economic and Social Review, pp. 57-73.

Chaudhary M. Aslam and Ahmed E., 2004, Globalization: WTO, Trade and Economic Liberalisation in Pakistan, Ferozsons, Lahore, forthcoming. 
Connolly, M. and D. Taylor, 1976, "Testing the Monetary Approach to Devaluation in Developing Countries" Journal of Political Economy, Vol. 84, No. 1.

Courche, T. J., 1973, "The Price-specie Flow Mechanism and Gold-Exchange Standard," in H. G. Johnson and A. K. Swoboda, (eds.) The Economic Common Currencies, Cambridge: Harvard University Press.

Courchene, T. J. and K. Singh, 1976, "Monetary Approach to the Balance Of Payments: An Emprical Analysis for Fourteen Industrial Countries" in M. Parkin and Zis, (eds.) Inflation in the World Economy, Manchester: Manchester University Press.

De Grauwe, P. 1976, "Monetary Interdependence and International Monetary Reform”, Lexington: Health.

Donna L. Bean, 1976, "International Reserve Flows and Money Market Equilibrium: The Japanese Case.” In Jacob A. Frenkel and Harry G. Johnson (eds.) The Monetary Approach to the Balance of Payments, George Allen Unwin

Genberg, A. Hans, 1976, "Aspects of the Monetary Approach to the Balance of Payments Theory: An Empirical Study of Sweden." In Jacob A. Frenkel and Harry G. Johnson (eds.) The Monetary Approach to the Balance of Payments, George Allen Unwin Ltd.

Geweke, John, 1978, "Testing the Exogoneity Specification in the Complete Dynamic Simultaneous Equation Model." Journal of Econometrics, Vol. 7, No. 2, pp. 163-185.

Government of Pakistan, Ministry of Finance, Economic Survey (2000-2001), Economic Affair Division, Islamabad. [Various Issues].

Guitian, Manual, 1976, "Balance of Payments as a Monetary Phenomenon.” In Jacob A. Frenke1 and Harry G. Johnson (eds.) The Monetary Approach to the Balance of Payments, George Allen Unwin Ltd.

Harberger, A. C., 1950, "Currency Depreciation, Income, and Balance of Trade” Journal of Political Economy, Vo1. 58.

Howard, M. and N. Mamingi, 2002, "The Monetary Approach to the Balance of Payments: An Application to Barbodas" The Singapore Economic Review, Vol. 47, No. 2, PP. 213-228 
Hossain, M. Akhter, 1988, "Theories of Inflation and Balance of Payments in Developing Countries: A Survey." The Indian Economic Journal, vol. 36, No.1, pp. 15-29.

International Monetary Fund, International Financial Statistics, Washington D.C: IMF [Various Issues].

Johannes, M. James, 1981, "Testing the Exogeneity Specification Underlying the Monetary Approach to the Balance of Payments." The Review of Economics and Statistics, Vol. 63, No. 1, pp. 29-34.

Kemal, A. R. Faiz, Bilquees and Ashfaque, H. Khan, 1980, "Estimates of Money Supply in Pakistan, 1959-60 to 1978-79." Pakistan Institute of Development Economics, Statistical Papers Series No.1.

Khan, M. Arshad, 1996, "The Balance of Payments Dis-equliberia, Monetary Policy and its Economic Impacts." M.Phil.Thesis, Department of Economics, Quaid-i-Azam University, Islamabad.

Khan, S. Mohsin, 1974, "Experiment with a Monetary Model for the Venezuela Economy.” IMF Staff Papers, Vo1. 2, pp. 389-413.

Khan, S. Mohsin, 1976, "A Monetary Model of Balance of Payments: The Case of Venezuela." Journal of Monetary Economics, Vo1. 2, No. 1, pp. 311-332.

Killick, T., 1981, "Policy Economics: A Text Book of Applied Economics on Developing Countries," London: Heinemann.

Kreinin, E. M. and H. L. Officer, 1978, "The Monetary Approach to the Balance of Payments: A Survey, Princeton, New Jersey: Princeton University Press.

Laursen, S. and L. A. Metzler, 1950, "Flexible Exchange Rates and the Theory of Employment" The Review of Economics and Statistics, Vol. 32.

Magee, Stephen P., 1976, "The Empirical Evidence of the Monetary Approach to Balance of Payments and Exchange Rates" American Economic Review Vol. 66 pp. 163-170.

Munde11, A. Robert, 1973, "The Balance of Payments Theory and Economic policy." The Macmillan Press Ltd, New York.

Mundell, R. A., 1968, International Economics, New York: Macmillan. 
Musa, M., 1976, "Tariff and the Balance of Payments; A Monetary Approach" In Jacob A. Frenkel and Harry G. Johnson (eds.) The Monetary Approach to the Balance of Payments, George Allen Unwin Ltd.

Naqvi, S. N. Haider, 1973, "The Balance of Payments Problems in Developing Countries." Pakistan Development Review, Vol. 12, No. 3, pp. 259272.

Nwaobi, G. C., 2003, "The Balance of Payments As a Monetary Phenomenon: An Econometric Case Study of Nigeria” Economic Working Papers.

Odedokun, M. O., 1997, "The Monetary Approach to Analysing Floating Exchange Rate Behavior in Developing Countries: Evidence from SubSaharan African Countries, 1986-1992" Journal of Development Economics, Vol. 52, Issue No. 2, pp. 463-481.

Robinson, J., 1937, “The Foreign Exchanges" in J. Robinson, (eds) Essays in the Theory of Employment, London: MacMillan.

Sohrab-ud-Din, 1985, "Monetary Approach to Balance of Payments: Evidence form Less Developed Countries." Indian Economic Journal, Vol. 33, No. 1, pp. 92-104.

Tinbergen, J., 1952, On the Theory Of Economic Policy, North-Holland: Amsterdam.

Vicolas, Mario et al, 1995, "Application of the Monetary Approach to the Balance of Payments." World Bank, Washington D.C.

Whitman, V. Marena, 1975, "Global Monetarism and The Monetary Approach to the Balance of Payments." Brookings Papers on Economic Activity 3, pp. 491-536.

Wilford, D. Sykes and Richard J. Zecher, 1979, "Monetary Policy and The Balance of Payments in Mexico: 1955-75." Journal of Money, Credit and Banking, Vol. 11, No. 3, pp. 340-347.

Zecher, J. Richard 1974 "Monetary Equilibrium and the International Reserves Flow in Australia." Journal of Finance, Vol. 29, No. 3, pp.1323-30. 